\title{
Comparison of Age of Thelarche between Obese and Normal Girls
}

\author{
Yunitasari, ${ }^{1}$ R.M.Ryadi Fadil, ${ }^{2}$ Fenny Dwiyatnaningrum ${ }^{3}$ \\ ${ }^{1}$ Faculty of Medicine Universitas Padjadjaran, ${ }^{2}$ Department of Child Health Faculty of Medicine \\ Universitas Padjadjaran/Dr. Hasan Sadikin General Hospital Bandung, ${ }^{3}$ Department of Anatomy \\ and Cell Biology Faculty of Medicine Universitas Padjadjaran
}

\begin{abstract}
Background: Childhood obesity has become a major concern in recent years. The increasing childhood obesity prevalence may occur as the result of food consumption with high content of calories, fat, cholesterol and the lack of physical activity. Obesity in children will also affect their pubertal development. Puberty is a period in which maturation of the reproductive function is achieved.In girls, the initial sign of puberty is thelarche, defined as the appearance of breast bud underneath the areola.The onset of puberty depends on many factors, one of them is nutritional status especially obesity. This study was conducted to compare the age of thelarche between obese and normal girls.
\end{abstract}

Methods: An analytical study using cross sectional method was conducted. This study was held in Bandung, West Java, Indonesia, during the period of September? October 2013. Data were obtained from 3 elementary schools, selected by multistage random sampling.The total subject was 46 . Data were analyzed using the Mann-Whitney and chi-square test.

Results: Thelarche occurred at age 9 years 4 months in the obese group compared to 11 years 2 months in the normal group. The analysis using Mann-Whitney test showed the difference was statistically significant $(\mathrm{p}<0.001)$. Based on age group, $42 \%$ obese girls attained thelarche between ages 8 ? 9 years, while $63 \%$ girls in the normal group attained thelarche between ages 11 ? 12 years. The analysis using chi- square test showed that the difference was statistically significant $(\mathrm{p}<0.001)$.

Conclusions: Thelarche occurs earlier in obese girls compared to normal girls. [AMJ.2016;3(3):411-5]

Keywords: Obesity, pubertal onset, thelarche

\section{Introduction}

Childhood obesity has become a major concern in recent years. The world prevalence had increased from $4.2 \%$ in 1990 to $6.7 \%$ in $2010 .^{1}$ In Indonesia, based on data from the Ministry of Health in 2010, the national prevalence rate of obesity in children aged 6-12 years reached $9.2 \%$ with higher prevalence in boys $(10.7 \%)$ compared to girls $(7.7 \%){ }^{2}$ This may occur as the result of food consumption with high content of calories, fat, cholesterol and the lack of physical activity. ${ }^{3}$

Obesity in children is associated with significant morbidities, such as obstructive sleep apnea syndrome, insulin resistance, hypertension, dyslipidemia, gallstones, and neurological problems. These complications may not become apparent until several years later. ${ }^{4}$ In addition, obesity in children will affect their pubertal development. ${ }^{5}$

Puberty is a period of transition from childhoodintoadulthoodinwhich development of secondary sexual characteristics starts to appear and maturation of the reproductive function is achieved. In general, girls start to develop puberty at 8-12 years of age. Thelarche is the initial sign of puberty in girls, defined as the appearance of breast bud underneath the areola. Based on Tanner classification of breast development, thelarce is defined as Tanner stage 2 . The onset of puberty depends on many factors, one of them is the nutritional status especially obesity. ${ }^{5} \mathrm{~A}$ research in the United States by Rosenfield et al. ${ }^{6}$ found that the prevalence of breast appearance (Tanner stage 2) at ages 8-9.6 years was higher in girls with excessive body mass index (BMI)

Correspondence: Yunitasari, Faculty of Medicine, Universitas Padjadjaran, Jalan Raya Bandung-Sumedang Km.21, Jatinangor, Sumedang, Indonesia, Phone: +62 82116222811 Email: yunitasari2020@yahoo.com 
compared to those with normal BMI.

Furthermore, abnormal puberty could also lead to various medical and psychological problems. Short stature, polycystic ovary syndrome (PCOS), menstrual disorder, and breast cancer may arise as the consequences of early puberty in girls. Psychosocial effects are especially a major concern in girls with precocious puberty. These girls may have poor self-esteem resulting from feeling of being different from their peers. They are also at risk for depression, anxiety, sexual abuse, risky sexual behavior (such as multiple sexual partner), unwanted pregnancy, behavioral and eating disorder. ${ }^{7}$

The aim of this study was to compare the age of thelarche between obese and normal girls.

\section{Methods}

An analytical study using cross sectional method was conducted. This study was held in Bandung, West Java, Indonesia, during the period of September to October 2013. Girls aged 8-12 years who experienced thelarche were included in this study. Data were obtained from west, central and east Bandung regions. Each of the three regions was represented by one elementary school (Sekolah Dasar/SD) which was selected by multistage random sampling. In the first stage, randomization was done at the district level, the three selected districts were Bandung Kulon, Sumur Bandung and Mandalajati, each represented west, central and east Bandung regions, respectively. In the second stage, randomization was performed at the school level in each district, the three selected schools were SD Negeri Tunas Harapan, SD Kartika Siliwangi IX-1, and SD Negeri Jatihandap 2. This study has been approved by the Health Research Ethics Committee and Bandung Education Department. Thelarche was defined as the appearance of breast bud underneath the areola, or Tanner stadium 2. The thelarche status was not measured by physical examination because of ethical reasons. Therefore, mothers were asked to fill a questionnaire which contained Tanner stage images of breast development with description of every stage to be matched with her daughter's condition. Before the questionnaire fulfillment, mothers were invited to school and given adequate explanation about the study and how to fill the questionnaire to minimize misunderstanding. The age of thelarche was measured from the date of birth until the date of questionnaire fulfillment. The age of 8-8 years 11 months were included in the 8-9 age group, 9-9 years 11 months in the 9-10 age group, $10-10$ years 11 months in the 10-11 age group, and 11-12 years in the 11-12 age group.

The manual weighing scale was used to measure body weight $(\mathrm{kg})$, while body height was measured by microtoise $(\mathrm{cm})$, both were calibrated during the measurement. The World Health Organization (WHO) AnthroPlus software version 1.0.4 was used to calculate BMI according to sex and age. Based on the 2007 WHO Reference, standard deviation (SD) of $>+2$ were classified as obese, while +1 until -2 were classified as normal.

Moreover, subjects were excluded if the questionnaire fulfillment was incomplete, they had chronic disease(s) or other disease(s) which could interfere their growth and development (for example thalassemia, tuberculosis, or heart disease), or if they were undergoing hormonal treatment. From the three schools mentioned above, there were 376 girls aged $8-12$ years. Out of the 376 girls, 205 met the inclusion criteria after consent from their parents were obtained. From these 205 girls, 108 were excluded because of incomplete questionnaire fulfillment. From 97 girls who completed the questionnaire, 68 girls were in Tanner stage 2. After the BMI according to sex and age was calculated, 19 girls were included in the obese group, and 27 girls with normal BMI were recruited for the comparison group. Thus, the total subject in this study was 46 . Data were analyzed using the Mann-Whitney and chi-square test It was considered statistically significant when $\mathrm{p} \leq 0.05$.

\section{Results}

The distribution of data was not normal; therefore median was used to describe the findings in this study. The age of subjects was younger in the obese group compared to the normal group. When the age of subjects was divided into groups, most subjects came from the 8-9 age group in obese girls and the 11-12 age group in normal girls. The body weight was higher in the obese group compared to the normal group. Conversely, body height was higher in the normal group compared to the obese group. Body mass index according to sex and age was calculated using the z-score. Based on this calculation, median BMI in the obese group was higher than the normal group (Table 1). 
Table 1 Respondents Characteristics

\begin{tabular}{|c|c|c|c|c|c|c|}
\hline \multirow[t]{2}{*}{ Characteristics } & \multicolumn{3}{|c|}{ Obese } & \multicolumn{3}{|c|}{ Normal } \\
\hline & n (\%) & Mean (SD) & Median & n (\%) & Mean (SD) & Median \\
\hline Age (years old) & & $9.36(1.00)$ & 9.33 & & $10.89(0.96)$ & 11.17 \\
\hline $8-9$ & $8(42)$ & & & $2(7)$ & & \\
\hline $9-10$ & $5(26)$ & & & $2(7)$ & & \\
\hline $10-11$ & $5(26)$ & & & $6(22)$ & & \\
\hline $11-12$ & $1(5)$ & & & $17(63)$ & & \\
\hline Body weight (kg) & & $42.80(7.59)$ & 45.00 & & 34.15 (6.07) & 36.00 \\
\hline Body height $(\mathrm{cm})$ & & $132.04(8.25)$ & 133.50 & & $141.85(8.46)$ & 143.10 \\
\hline BMI-for-age(z-score) & & $2.49(0.46)$ & 2.28 & & $-0.29(0.83)$ & -0.33 \\
\hline Total & $19(100)$ & & & $27(100)$ & & \\
\hline
\end{tabular}

When the age of subjects was divided into groups, the difference in the age of thelarche was clearly visible between the obese and normal group (Table 3). In the obese group, most girls attained thelarche at the 8-9 age group; there was only one girl who attained thelarche at the 11-12 age group. Otherwise, in the normal group, most girls attained thelarche at the 11-12 age group. The statistical analysis using chi- square test showed that the difference in the age of thelarche between the obese and normal group was statistically significant $(\mathrm{p}<0.001)$.

\section{Discussion}

The data above showed that thelarche occured earlier in obese girls compared to girls with normal BMI, and the difference was statistically significant. This finding is consistent with a study in Padang by Rini et al. ${ }^{8}$ who found that obese girls started puberty at 121 months compared to 132.43 months in girls with normal BMI, although there was no

Table 2 Comparison of Age of Thelarche between Obese and Normal Girls

\begin{tabular}{cccccc}
\hline & \multirow{2}{*}{$\mathbf{n}$} & \multicolumn{3}{c}{ Age of thelarche (years old) } & \multirow{2}{*}{$\mathbf{p}$} \\
\cline { 3 - 5 } & & Mean (SD) & Median & Minimum-maximum & \\
\hline Obese & 19 & $9.36(1.00)$ & 9.33 & $8.00-11.42$ & $<0.001$ \\
Normal & 27 & $10.89(0.96)$ & 11.17 & $8.00-11.83$ & \\
\hline
\end{tabular}

Note: $\mathrm{SD}=$ Standard Deviation; Mann-Whitney test

Table 3 Comparison of Age of Thelarche between Obese and Normal Girls Based on Age Group

\begin{tabular}{|c|c|c|c|c|c|c|c|c|c|c|c|c|}
\hline & & \multicolumn{10}{|c|}{ Age of thelarche (years old) } & \multirow{3}{*}{ p } \\
\hline & & \multicolumn{2}{|c|}{ 8-9 } & \multicolumn{2}{|c|}{ 9-10 } & \multicolumn{2}{|c|}{ 10-11 } & \multicolumn{2}{|c|}{ 11-12 } & \multicolumn{2}{|c|}{ Total } & \\
\hline & & $\mathrm{n}$ & $(\%)$ & $\mathrm{n}$ & $(\%)$ & $\mathrm{n}$ & $(\%)$ & $\mathrm{n}$ & $(\%)$ & $\mathrm{n}$ & $(\%)$ & \\
\hline \multirow[t]{3}{*}{ BMI } & Obese & 8 & $(42)$ & 5 & $(26)$ & 5 & $(26)$ & 1 & (5) & 19 & $(100)$ & $<0.001$ \\
\hline & Normal & 2 & (7) & 2 & (7) & 6 & $(22)$ & 17 & $(63)$ & 27 & $(100)$ & \\
\hline & Total & 10 & (22) & 7 & (15) & 11 & (24) & 18 & (39) & 46 & $(100)$ & \\
\hline
\end{tabular}

Note: chi-square test; BMI=body mass index 
significant relationship between BMI and the age of pubertal onset $(\mathrm{p}=0.08)$. Additionally, Rosenfield et al. ${ }^{6}$ compared attainment of stage 2 breast development in girls with normal and excessive BMI from the Third National Health and Nutrition Examination Survey (NHANES III) subjects, and this study found that girls with excessive BMI were more likely to exhibit Tanner stage 2 at ages 8 (OR: 3.86) through 9.6 (OR: 2.02) years compared to those with normal BMI.

The critical weight hypothesis proposed by Frischand Revelle ${ }^{9}$ in 1971 may serve as an explanation for the above findings. According to this hypothesis, certain minimum body fat is needed for pubertal development. This theory emphasizes leptin, a hormone produced by adipocytes, as the main actor in this process. Leptin has the capability to send signals to the hypothalamus regarding body fat storage. Thus, as soon as the body fat storage is sufficient, leptin will send signal to the hypotalamus to activate gonadotropinreleasing hormone(GnRH) which will stimulate gonadotropin secretion.

Normally, thelarche in puberty reflects the activation of GnRH-gonadotropin axis. However, in obese children, a further study may be needed to find out whether or not the earlier thelarche is also preceded by maturation of this axis, because estrogen from any source can stimulate breast tissue development. Furthermore, adipose tissue contains aromatase which is able to produce estrogen from adrenal androgen precursor. Therefore, estrogenization in obesity may occur without hypotalamus-pituitary-ovarium axis maturation. ${ }^{5}$ This theory was supported by Jasik and Lustig ${ }^{10}$ who found that the tempo of pubertal development (time from thelarche to menarche) was slowed in obese girls, this may suggest estrogenization without central maturation.

As a consideration, weight gain during puberty is physiologic since the increased estrogen secretion will stimulate the growth of adipose tissue. Thus, early puberty from any cause could result in increase adiposity. ${ }^{5}$ Current studies showed inconsistent results regarding the definite direction of causation between adiposity and sexual maturation. However, a longitudinal study by Lee et al. ${ }^{11}$ examined the association between the weight status in early childhood and the onset of puberty. Parents and children were recruited through hospital visits to mothers shortly after birth in 1991. Anthropometric data were measured during laboratory visits at 36 months, 54 months, and grade $1,4,5,6$, while puberty status was measured when girls were in grade 4-6. The result of this study found that starting at 36 months of age, higher BMI z-score at all of the ages was strongly associated with an earlier onset of puberty. This finding showed that obesity preceded early onset of puberty rather than earlier puberty result in adiposity.

There were several limitations in this study. The questionnaire filled out by mothers could lead to subjectivity in the assessment of thelarche, therefore physical examination (inspection and palpation) by experts is preferable to minimize subjectivity. The used of BMI as a measurement for nutritional status in this study could result in missclassification since it could not distinguish between weight caused by fat and muscle tissue. In addition, the method in this study could not be used to classify girls with earlier or later onset of thelarche as having precocious or delayed puberty, because the subjects of this study were taken from 8-12 years age range, which is the normal age range for puberty. In conclusion, thelarche occurs earlier in obese girls compared to normal girls. Suggestions for a future study are to increase the sample size and involve other pubertal milestones (pubarche, menarche) in the measurement.

\section{References}

1. de Onis M, Blössner M, Borghi E. Global prevalence and trends of overweight and obesity among preschool children. Am J ClinNutr.2010;92(5):1257-64.

2. Badan Penelitian dan Pengembangan Kesehatan Kementerian Kesehatan RepublikIndonesia. Status GiziAnakUmur 6-12 Tahun.Dalam:Riset Kesehatan Dasar 2010. Jakarta: Badan Penelitian dan Pengembangan Kesehatan Kementerian Kesehatan RepublikIndonesia; 2010.

3. Hidayati SN, Irawan R, Hidayat B. Obesitas pada anak. Divisi Nutrisi dan Penyakit Metabolik Bagian/SMF Ilmu Kesehatan AnakFakultas Kedokteran Unair/RS dr Soetomo. Pediatrik[Online Journal] 2006 [cited in February17th 2013]. Available at:http://old.pediatrik.com.

4. Lee YS. Consequences of childhood obesity. Ann Acad Med Singapore. 2009;38(1):757.

5. Solorzano CMB, McCartney CR. Obesity and the pubertal transition in girls and boys. Reproduction. 2010;140(3):399-410.

6. Rosenfield RL, Lipton RB, Drum ML. 
7. Rosenfield RL, Lipton RB, Drum ML. Thelarche, pubarche, and menarche attainment in children with normal and elevated body mass index. Pediatrics. 2009;123(1):84-8.

8. Golub MS, Collman GW, Foster PM, Kimmel CA, Rajpert-De Meyts E, Reiter EO, et al. Public health implications of altered puberty timing. Pediatrics. 2008;121Suppl3:S218-S30.

9. Rini EA, Desdamona E. Usia awitan pubertas dan beberapa faktor yang berhubungan pada murid SD di Kota Padang. Sari Pediatri. 2007;9(4):227-32.

10. Frisch RE, Revelle R. Height and weight at menarche and a hypothesis of menarche. Arch Dis Child.1971;46(249):695-701.

11. Jasik CB, Lustig RH. Adolescent obesity and puberty: the "perfect storm". Ann N Y Acad Sci. 2008;1135(1):265-79.

12. Lee JM, Appugliese D, Kaciroti N, Corwyn RF, Bradley RH, Lumeng JC. Weight status in young girls and the onset of puberty. Pediatrics. 2007;119(3):e624-30. 